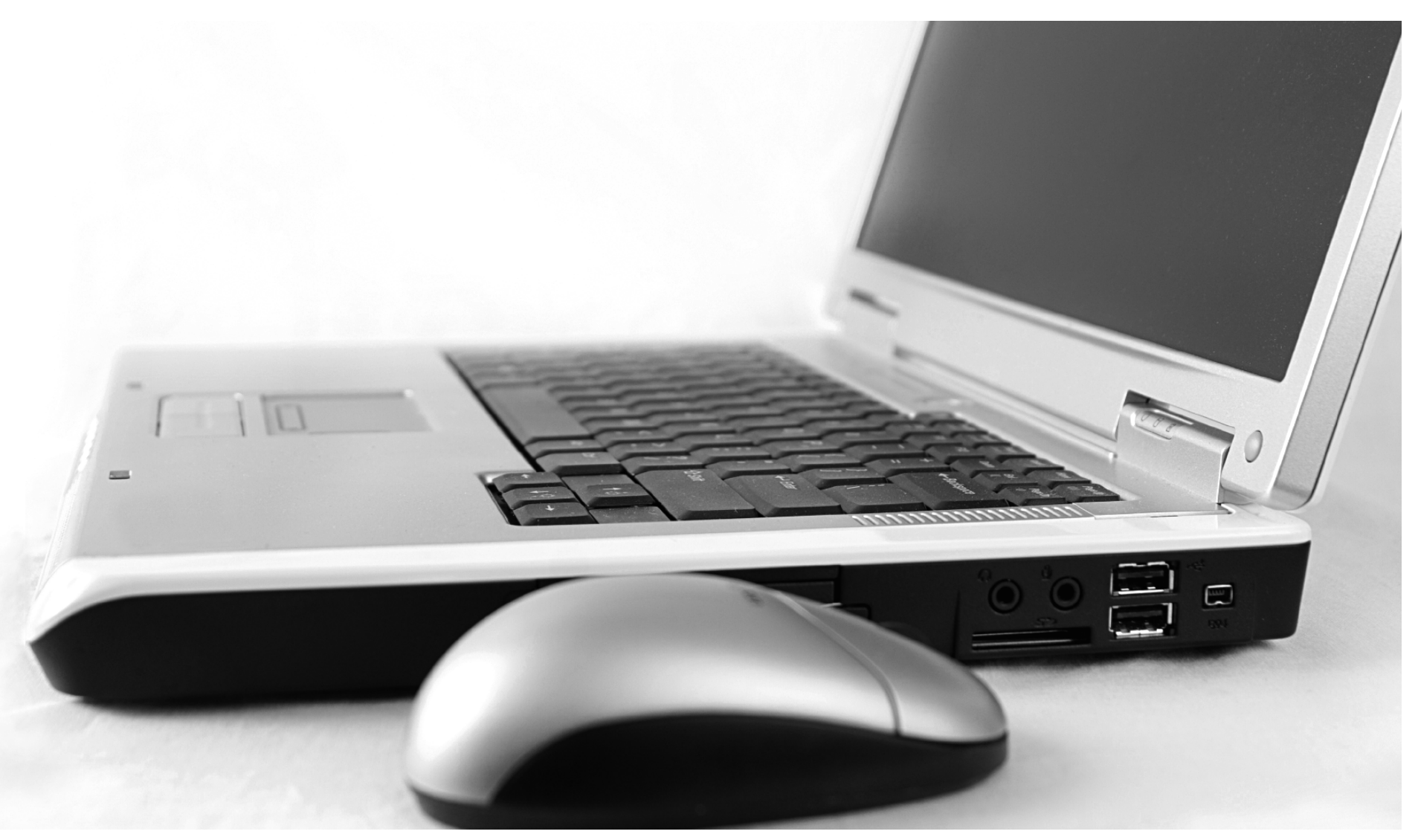

\title{
Journal authors!
}

\section{Submit your manuscripts online to Canadian Journal of}

\section{Emergency Medicine at http://mc.manuscriptcentral.com/cjem.}

Speeds up and simplifies the publishing process.

Keeps you informed from submission to acceptance.

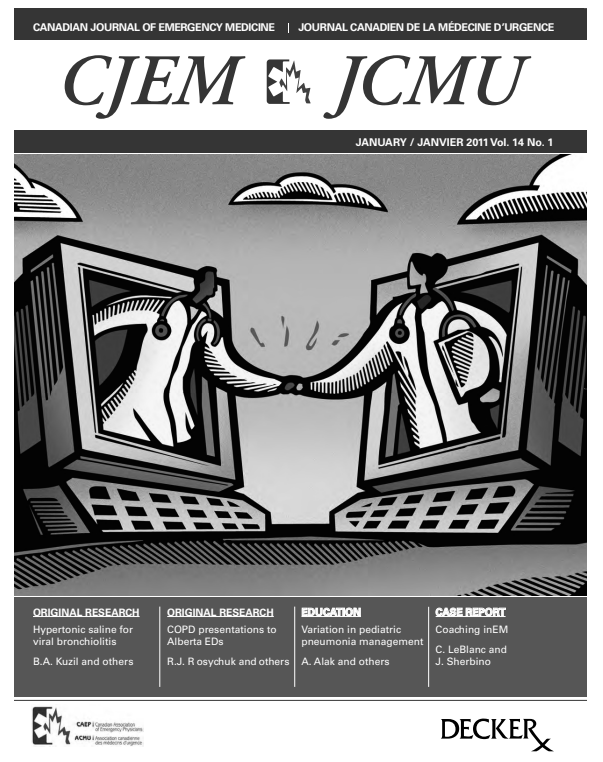

Submit your manuscripts on Manuscript Central. It's the online tool that makes submission easy and expedites the peer review process. You can even track the progress of your manuscript through to acceptance.

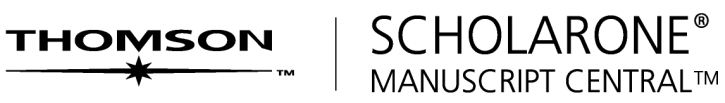

Manuscript Central ScholarOne are registered trademarks of Thomson Scientific.

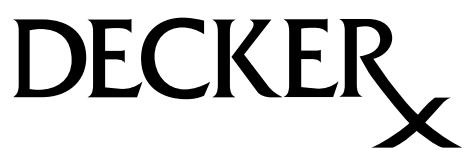




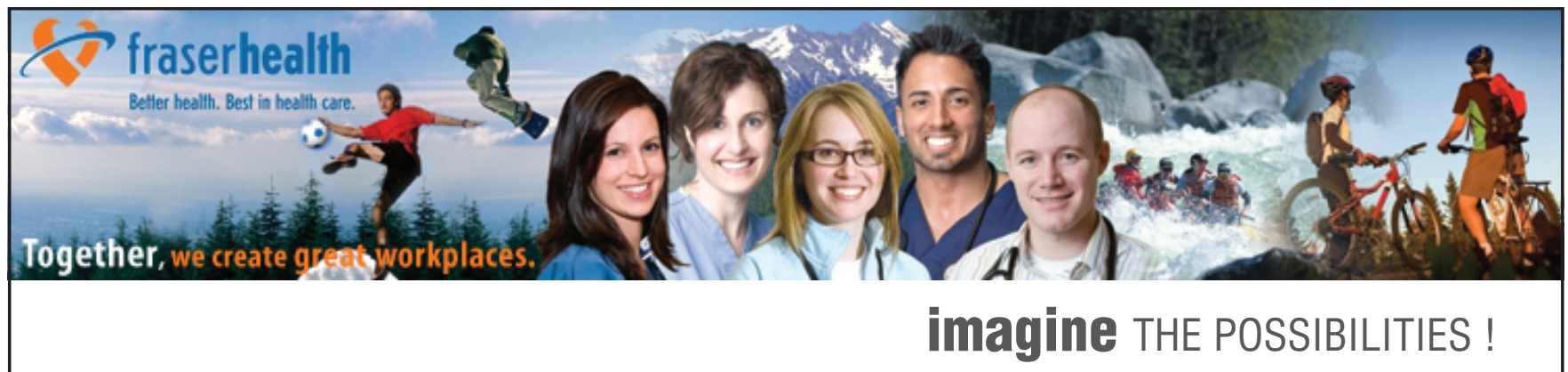

\section{EMERGENCY PHYSICIANS}

Explore an opportunity to join a well established collegial group of ER Physicians from the Royal Columbian and Eagle Ridge Hospital Emergency Departments in beautiful British Columbia.

The Royal Columbian Hospital is a tertiary care teaching hospital located in New Westminster, BC. It is the region's high acuity tertiary care centre and designated Trauma Receiving Site with a catchment of over 1.5 million people. The department has over 65,000 annual patient visits, including about $15 \%$ pediatrics. Eagle Ridge Hospital, located in Port Moody, is a community based hospital with over 45,000 annual ED visits per year. Both hospitals are academic teaching sites for University of British Columbia medical students and residents. We are part of the UBC Emergency Medicine FRCP and CCFP training programs. There is an active Emergency Medicine Research section within our group.
Both communities are suburban, and part of the greater Vancouver area (about 20 - 30 minutes from downtown Vancouver, and 1.5 hours from Whistler Mountain).

The successful candidate will be FRCPC or CCFP (EM) certified with experience in trauma, prepared to provide full time clinical care. Compensation is via an Alternate Payment Plan provided by the Ministry of Health.

Applicants must be eligible for licensure in British Columbia. Interested individuals should submit inquiries and/or CV to:

Dr. Shawn Janes

Royal Columbian Hospital

330 E. Columbia Street

New Westminster, BC

V3L 3W7

Email: janes.shawn@gmail.com

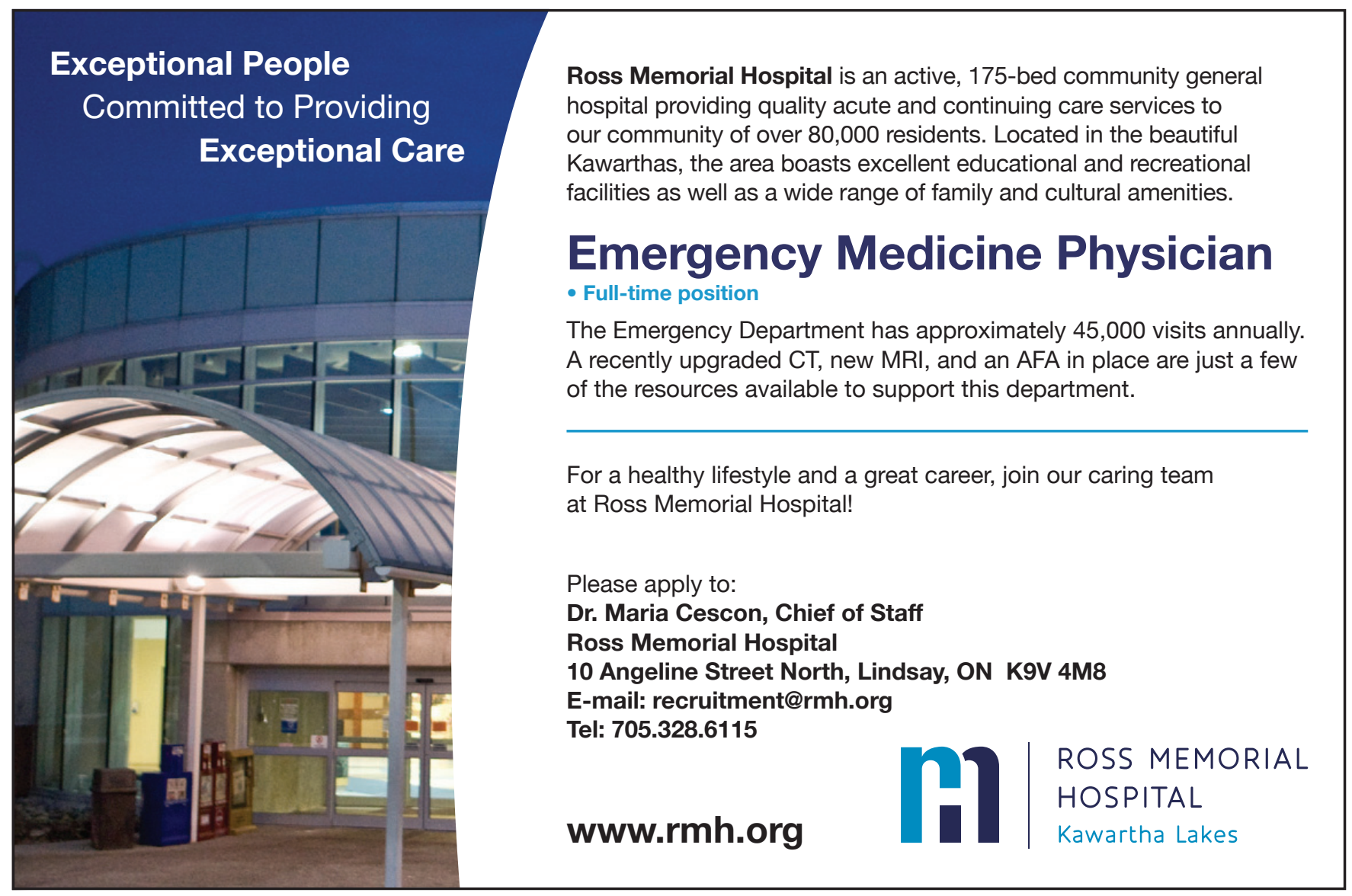




\section{EMERGENCY PHYSICIANS, Nanaimo, Vancouver Island}

The Department of Emergency Medicine at Nanaimo Regional General Hospital (NRGH) invites certified emergency physicians to apply to join our progressive, collegial group of $20+$ in the ocean front community of Nanaimo, BC.

The Nanaimo Emergency Physicians Association provides emergency and trauma team leadership services in the busiest emergency department on Vancouver Island at the NRGH in a brand new, state-of-the-art department which opened October, 2012. The NRGH emergency department is a referral center for the central Vancouver Island catchment area with an annual census of 60,000 patient visits and has back-up from all of major specialties.

Nanaimo (population 87,000 ) is a growing, vibrant, and family-oriented community with proximity to Victoria and
Vancouver. Having one of the best climates in Canada, and access to amazing recreational activities, make Nanaimo an ideal location for outdoor enthusiasts. Nearby Mt. Washington offers excellent downhill and cross-country facilities and frequently boasts the deepest snow pack in North America.

Whether your interests be clinical, administrative, educational, research, or simply a great place to live and work, practicing emergency medicine at NRGH will meet and exceed your professional and lifestyle goals.

To apply, please send your CV, cover letter and the names of three references to:

Brenda Warren,

Physician Recruitment Manager

Email: physicians@viha.ca or Fax: (250) 716-7747
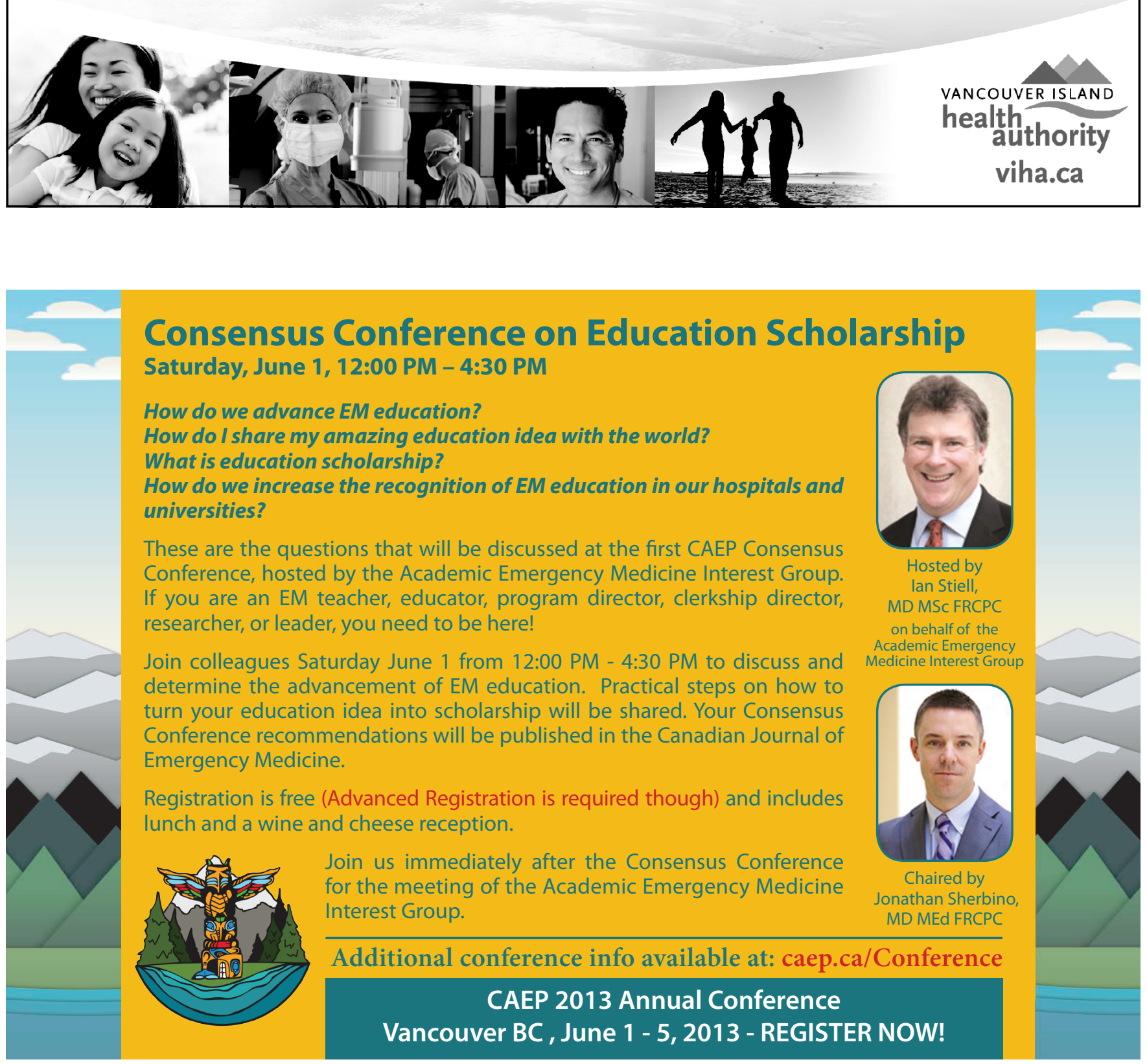


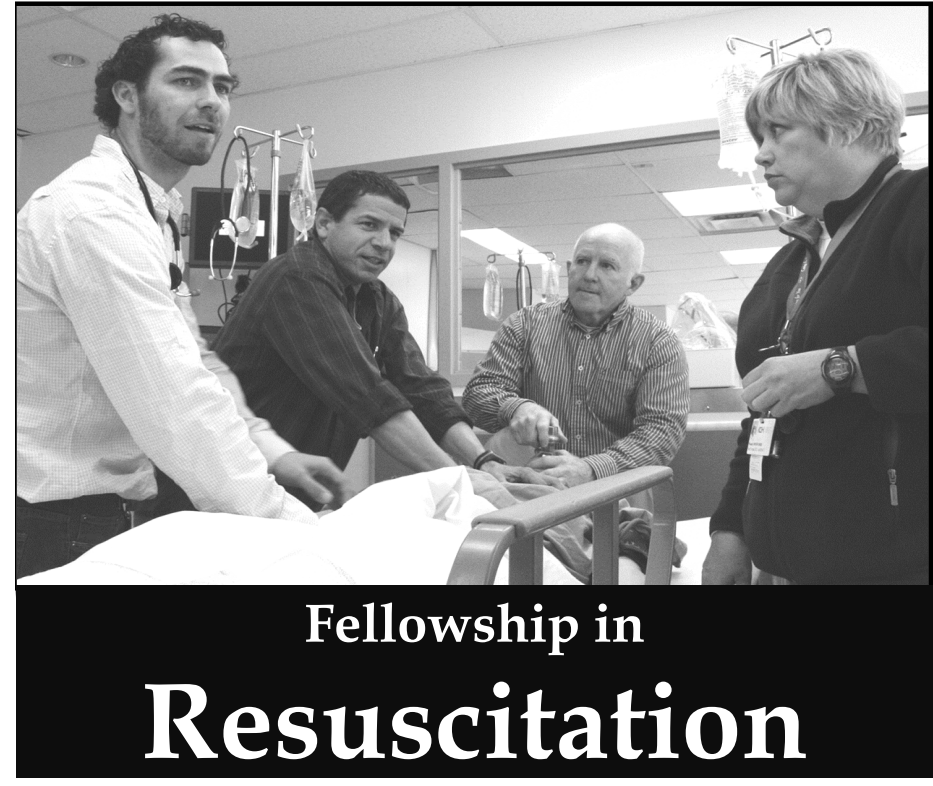

Queen's University and the Kingston Resuscitation Institute are offering Fellowship training in Resuscitation and Reanimation. Started in 2008, the program runs from July 1 to June 30 and will consider emergency residents interested in overlap during the $4^{\text {th }}$ year of a 5-year training program.

Students experience a spiral curriculum with three arms: the Science of Resuscitation Medicine; Medical Education and Simulation; and Leadership and Crisis Resource Management. For more information visit:

www.resuscitationinstitute.org/index.cfm/courses/resuscitation-fellowship/

or contact Dr. Daniel Howes: howesd@kgh.kari.net

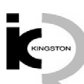

\section{EMERGENCY PHYSICIAN}

\section{Guelph, Ontario}

Guelph General Hospital Emergency Group is seeking full-time and part-time Emergency Physicians beginning Spring 2013. Join a democratic physician group to work in a modern, quality-focused ED serving $>55,000$ patients annually. We offer excellent remuneration under an Alternate Funding model and generous time off. FRCP-EM, CCFP-EM or equivalent ED experience required.

Guelph is a beautiful and vibrant university city of over 120,000 located within close proximity of Toronto, London and Hamilton. Associated with one of the fastest growing economic regions in Canada, Guelph offers a wide variety of educational, cultural, recreational and sporting activities.

\section{For information contact:}

Dr. lan Digby, Chief of Emergency Medicine

Guelph General Hospital

Email: idigby@gghorg.ca

Tel: $519-837-1401$

Fax: 519-837-0133

Suitable applicants will require a current CV, cover letter, and 3 references.

GUELPH GENERAL HOSPITAL

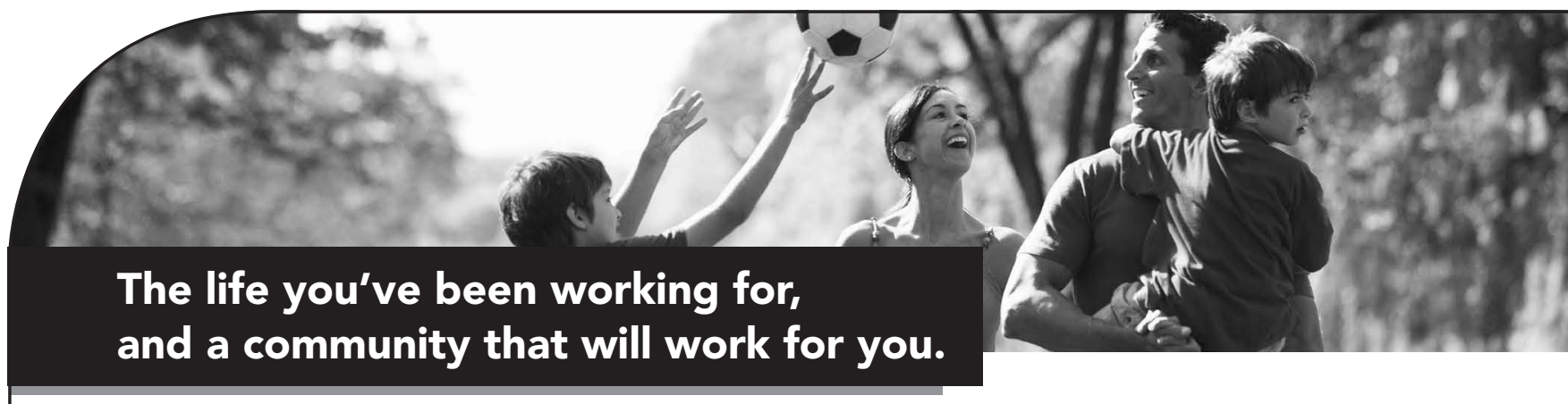

BRANTFORD, ONTARIO is a charming town with a proud heritage in the scenic Grand River Valley. We offer hometown hospitality that's just a short trek to several urban centres and major universities. From outdoor recreation to a blend of culture, arts, and tradition, balance your hard work with the lifestyle you deserve.

\section{EMERGENCY MEDICINE PHYSICIAN}

With a team of career-oriented physicians delivering primary care, supported by a core of committed local family physicians, we tend to approximately 45,000 visits annually. We also run a parellel Urgent Care centre with volumes of approximately 17,000 . We boast a comprehensive facility strengthened by a field of specialty physicians as well as Emergency Department Echo with five certified master instructors. Part-time and full-time positions available.

We're continuously looking to expand our organization and are always open for a conversation. Contact Alice Preston, Medical Recruitment and Retention Specialist at (519) 751-5544 ext. 2354 or e-mail apreston@bchsys.org.

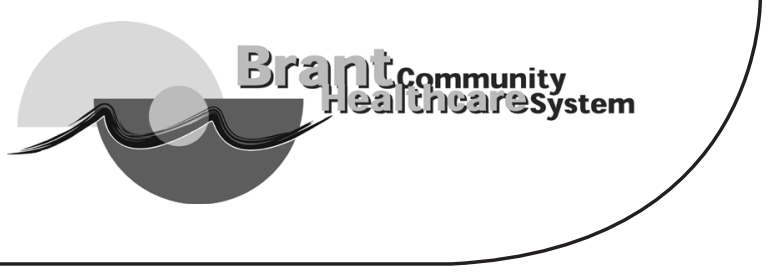

\section{WWW.BCHSYS.ORG}




\section{GRAND RIVER HOSPITAL}

\section{EMERGENCY PHYSICIANS \\ Kitchener-Waterloo} St.Marys

Come and explore an opportunity to join a well-established group of ED Physicians in Kitchener-Waterloo. We are looking for full-time emergency physicians to join our collegial group, which covers two busy Emergency Departments.

St. Mary's General Hospital (SMGH) provides the region with cardiac and respiratory programs. SMGH sees approximately 45,000 ED patients annually.

Grand River Hospital ( $\mathrm{GRH}$ ) provides the regional district stroke intervention program, as well as a full range of specialist services (excluding neurosurgery). GRH sees an average of 55,000 ED patients per year.

Both departments have dedicated ultrasound machines and CEUS Independent Practitioners who can help train you toward IP status. Clinical Decision Units exist at both hospitals and both departments are supported by Nurse Practitioners. Both sites have Minor Treatment areas.

There is an equitable distribution of day, evening, night and weekend shifts between all members. Remuneration is under a competitive alternativefunding plan.

The successful candidate will be CCFP-EM, ABEM, or FRCPC certified. Physicians with emergency experience will also be considered. Applicants must be eligible for licensure in the Province of Ontario.

Interested individuals should submit inquiries and/or CV to:

\section{Dr. Sam Hasan}

Recruitment Coordinating Physician

Kitchener-Waterloo Emergency Medicine Associates

St. Mary's General Hospital \& Grand River Hospital

Email drhasan sam@yahoo.com

Tel 519-749-4300 x3892 • Fax 519-749-4293

www.smgh.ca • www.grhosp.on.ca

\section{Emergency Room Physicians}

\section{EASTERN REGIONAL HEALTH AUTHORITY}

Eastern Regional Health Authority invites applicants for the positions of Emergency Room Physician with the GB Cross Memorial Hospital in Clarenville, Newfoundland and the Carbonear General Hospital in Carbonear, Newfoundland.

In Clarenville the successful applicant will join 3 other full-time physicians. The usual pattern is an OR shift, followed by two dayshifts and two night shifts, followed by three days off. There is some room for flexibility. The successful applicant will be expected to work a minimum of 40 hours weekly.

In Carbonear the successful applicant will join 6 other full-time/part-time physicians. The usual pattern is two day shifts followed by two night shifts with room for flexibility.

The hourly rate will be paid in accordance with the Memorandum of Agreement between the Government of Newfoundland and Labrador and the Newfoundland and Labrador Medical Association. NOTE; OR Shifts are paid on a Fee for Service basis.

Candidates must have previous experience working as an Emergency Room Physician, be up-to date with ATLS/ACLS/PALS and be eligible for licensure with the College of Physicians and Surgeons of Newfoundland and Labrador.

For more information regarding Eastern Health and practicing in Newfoundland and Labrador please visit the following websites: www easternhealth ca and www.practicenl.ca. For more information about Memorial University please visit www.mun.ca.

Interested applicants should send curriculum vitae and the names of three references to:

\begin{tabular}{|c|c|}
\hline $\begin{array}{r}\text { Dr. John Guy } \\
\text { Director Medical Services, Eastern Health } \\
300 \text { Prince Philip Drive } \\
\text { St. John's, Newfoundland A1B 3V6 }\end{array}$ & $\begin{array}{l}\text { Eastern } \\
\text { Health } \\
\text { Healo }\end{array}$ \\
\hline $\begin{array}{r}\text { Fax \# (709) 778-6307 } \\
\text { Email: john.quy@easternhealth.ca }\end{array}$ & Newtound and $\mathbb{Q}$ Lathato \\
\hline
\end{tabular}

\section{(Regina Qu'Appelle}

\section{Emergency Physician -Full-time/Locum}

We are seeking team-oriented and professional Emergency Physicians to be part of our dynamic and expanding Emergency Medicine department. Physicians provide coverage for all shifts in an established rotation that averages 32 hours per week. Emergency services are provided 24/7 at two sites within the Regina Qu'Appelle Health Region; the Pasqua Hospital which is a 218 bed community facility and the Regina General Hospital which has 403 beds and is the trauma center for southern Saskatchewan. Both sites are fully supported with subspecialty coverage including $3 \mathrm{CT}$ scanners and $2 \mathrm{MRI}$ 's.

\section{Qualifications}

The candidate will be EM certified with CCFP (EM), ABEM or FRCPC - EM and be eligible for a license to practice in Saskatchewan. Candidates with extensive EM experience will also be considered. In accordance with immigration requirements, preference will be given to Canadian citizens and permanent residents of Canada.

Please submit curriculum vitae to:

Kimberly Merk, Program Associate, RQHR kimberly.merk@rqhealth.ca 


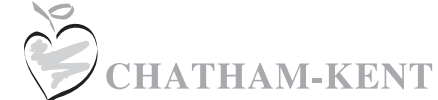 \\ Health Alliance}

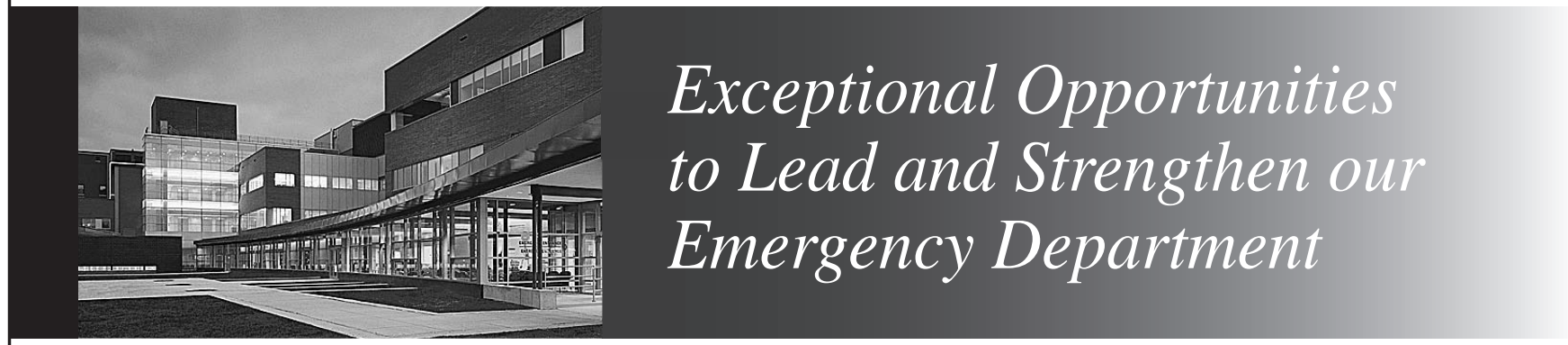

Chatham-Kent Health Alliance is an innovative and progressive, 300-bed community hospital with campuses in Chatham and Wallaceburg. Our focus is Patients, People, Performance and Innovation and our strategic directions support our Vision - An Exceptional Community Hospital. Setting Standards - Exceeding Expectations. We are equipped with state-of-the-art facilities and technologies, and operate at national best practice levels. Come join us to build, grow and advance your career in a workplace where you will be respected and supported.

If you have a reputation as an excellent physician and for developing sound working relationships with your colleagues, this is an exciting time to be part of the team that is building on the strengths of our Emergency Program. Our Chatham and Wallaceburg campus Emergency Departments provide 24/7 care and receive approximately 60,000 visits per year. That's where you can make a difference. Chatham-Kent Health Alliance has strong educational affiliations with the Western University Schulich School of Medicine \& Dentistry, and teaching opportunities are available.

\section{Chief \& Medical Director of Emergency Department}

You are a visionary leader with a commitment to innovation and quality of care, ready to oversee all aspects of the clinical practice within the Department and manage key operations, from quality and human resources to education and utilization. You will be instrumental in taking our Emergency Department to new levels of excellence. You combine 5 or more years of demonstrated clinical practice and medical leadership experience with an ability to take charge and deliver results.

\section{Emergency Department Physicians}

We have both full-time and part-time opportunities for Emergency Physicians whose 1 to $3+$ years of clinical practice experience are coupled with CCFP (EM) or FRCP credentials and/or ER experience.

Membership, or eligibility for membership, in the College of Physicians and Surgeons of Ontario is required for all positions, as are ACLS and ATLS. Isn't it time you seized the opportunity to join a great team determined to make a difference?

To learn more about us and our community, visit our website today. For further details about these positions, select "Physician Opportunities" under "Join our Team". Interested applicants should submit a letter of interest in the position, together with a current CV, to: Dr. Martin Lees, Vice President, Medical Affairs/Chief of Staff, at mlees@ckha.on.ca.

www.ckha.on.ca 


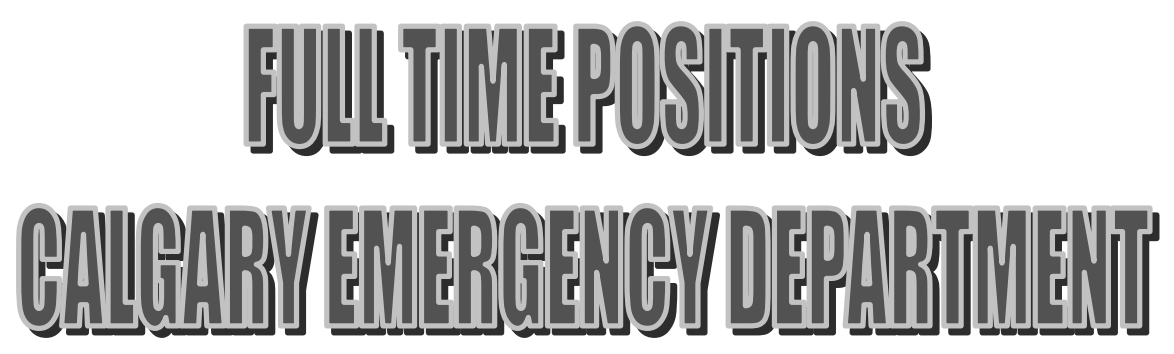

The Department of Emergency Medicine (Alberta Health Services - Calgary Zone) is now accepting applications for full time emergency physicians. Flexible start dates are available, beginning throughout 2013.

The Calgary Department of Emergency Medicine encompasses two emergency medicine residency programs and four hospital sites seeing over 260,000 patients per year. The fourth site, the South Health Campus opened in January 2013 and has one of Canada's most advanced Emergency Departments. In addition to a full spectrum of high acuity clinical medicine, trauma and cardiac care, we have active programs in human patient simulation and EM ultrasound, and Calgary is the home of STARS (Shock Trauma Air Rescue Society), one of North America's longest operating rotary wing aero medical systems. The Calgary Department of Emergency Medicine has a growing academic program with research and teaching opportunities.

Calgary is a vibrant, multicultural city (population 1.2 million) near the Rocky Mountains, Banff National Park and Lake Louise with a full range of recreational, sports and cultural opportunities. Alberta emergency physicians are among the highest paid in North America, and enjoy a flexible work/life balance while working is a highly supportive, collegial environment.

Requirements: CCFP (EM), ABEM or FRCPC training and certification is required, as well as eligibility for licensure in the province of Alberta.

Interested applicants should forward their curriculum vitae, cover letter and have 3 letters of recommendation sent to:

Scott H. Banks, MBA, CHRP, CITP

Zone Department Manager, Emergency Medicine

Foothills Medical Centre

Room C231, $1403-29^{\text {th }}$ St NW

Calgary, AB T2N 2 T9

\section{Email: scott.banks@albertahealthservices.ca}
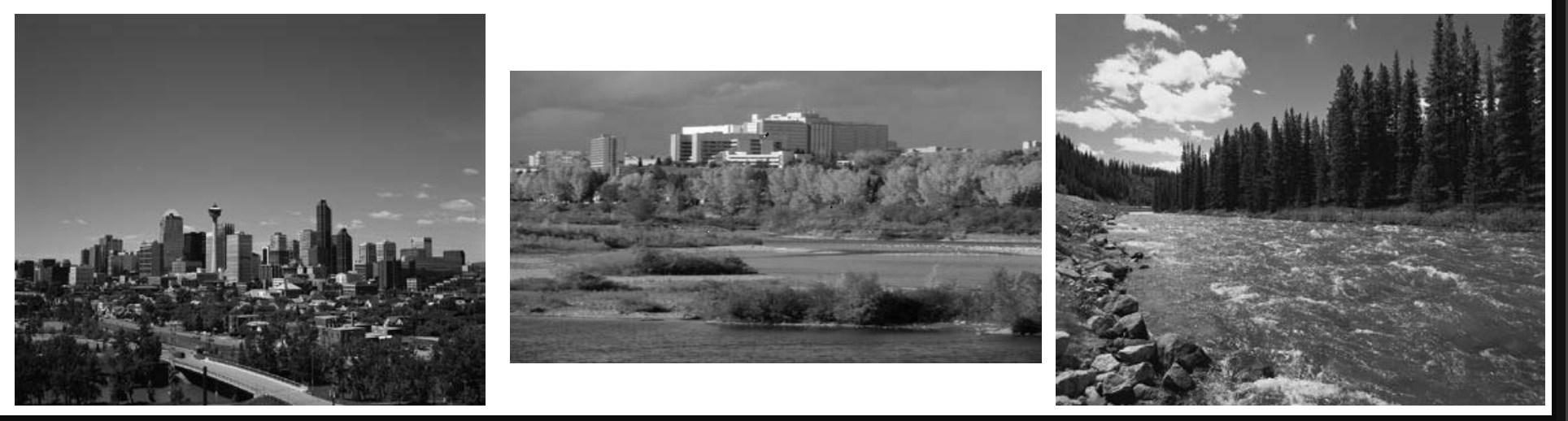


\section{CYANOKIT' $5 g$}

\section{PRESCRIBING SUMMARY}

\section{(1)}

Patient Selection Criteria

\section{THERAPEUTIC CLASSIFICATION: Antidote (Powder for solution for infusion)}

INDICATIONS AND CLINICAL USE: Cyanokit ${ }^{\circledR}$ contains hydroxocobalamin, an antidote indicated for the treatment of known or suspected cyanide poisoning. Cyanokit ${ }^{\circledR}$ is to be administered together with appropriate decontamination and supportive measures.

Identifying patients with cyanide poisoning: Cyanide poisoning may result from inhalation, ingestion, or dermal exposure to various cyanide containing compounds, including smoke from closed space fires. Sources of cyanide poisoning include hydrogen cyanide and its salts, cyanogens, including cyanogenic plants, aliphatic nitriles, or prolonged exposure to sodium nitroprusside. The presence and extent of cyanide poisoning are often initially unknown. There is no widely available, rapid, confirmatory cyanide blood test. Treatment decisions must be made on the basis of clinical history and signs and symptoms of cyanide intoxication. If clinical suspicion of cyanide poisoning is high, Cyanokit ${ }^{\boxplus}$ should be administered without delay.

Table 1. Common Signs and Symptoms of Cyanide Poisoning

\begin{tabular}{|l|l|}
\hline Symptoms & Signs \\
\hline - Headache & - Altered Mental Status (e.g., confusion, disorientation) \\
- Confusion & - Seizures or Coma \\
- Dyspnea & - Mydriasis \\
- Chest tightness & - Tachypnea/Hyperpnea (early) \\
- Nausea & - Bradypnea/Apnea (late) \\
& - Hypertension (early)/Hypotension (late) \\
& - Cardiovascular collapse \\
& - Vomiting \\
& - Plasma lactate concentration $\geq 8 \mathrm{mmol} / \mathrm{L}$ \\
\hline
\end{tabular}

In some settings, panic symptoms, including tachypnea and vomiting, may mimic early cyanide poisoning signs. The presence of altered mental status (confusion and disorientation) and/or mydriasis is suggestive of true cyanide poisoning, although these signs can occur with other toxic exposures as well.

Smoke inhalation: Not all smoke inhalation victims will necessarily have cyanide poisoning, and may present with burns, trauma, and exposure to additional toxic substances making a diagnosis of cyanide poisoning particularly difficult. Prior to the administration of Cyanokit, smoke-inhalation victims should be assessed for the following:

- exposure to fire smoke in an enclosed area

- soot present around mouth, nose and/or oropharynx

- altered mental status

Use with Other Cyanide Antidotes: The safety of administering other cyanide antidotes simultaneously with Cyanokit ${ }^{\oplus}$ has not been established. If the decision is made to administer another cyanide antidote with Cyanokit, these medicinal products must not be administered concurrently in the same intravenous line (see DOSAGE AND ADMINISTRATION).

Geriatrics ( $\geq 65$ years of age): Approximately 50 known or suspected cyanide victims aged 65 or older received hydroxocobalamin in clinical studies. In general, the safety and effectiveness of hydroxocobalamin in these patients was similar to that of younger patients. No adjustment of dose is required in elderly patients.

Pediatrics (< 18 years of age): Limited safety and efficacy data are available for pediatric patients. In infants to adolescents, the dose of Cyanokit is $70 \mathrm{mg} / \mathrm{kg}$ (see DOSAGE AND ADMINISTRATION).

CONTRAINDICATIONS: None.

SPECIAL POPULATIONS: For use in special populations, see WARNINGS AND PRECAUTIONS, Special Populations.

\section{Safety Information}

\section{WARNINGS AND PRECAUTIONS}

General: Emergency Patient Management - In addition to Cyanokit, ${ }^{\oplus}$ treatment of cyanide poisoning must include immediate attention to airway patency, adequacy of oxygenation and hydration, cardiovascular support, and management of any seizure activity. Consideration should be given to decontamination measures based on the route of exposure. Cyanokit ${ }^{\oplus}$ does not substitute for oxygen therapy and must not delay the set up of the above measures.

Cardiovascular: Transient, generally asymptomatic, increase in blood pressure may occur in patients receiving hydroxocobalamin. The maximal increase in blood pressure has been observed toward the end of infusion.

Immune: Known hypersensitivity to hydroxocobalamin or vitamin $B_{12}$ must be taken into benefit-risk consideration before administration of Cyanokit, since hypersensitivity reactions may occur in patients receiving hydroxocobalamin. Allergic reaction may include anaphylaxis, chest tightness, edema, urticaria, pruritus, dyspnea and rash.

Renal: Based on its vasopressor effect, hydroxocobalamin may cause vasoconstriction of the renal vasculature. Since no more than two injections of hydroxocobalamin are to be administered it is unlikely that this will have any effect in patients with normal renal function; the outcome in patients with impaired renal function is unknown.

Sexual Function/Reproduction: No animal studies on male and female fertility and early embryonic development to implantation have been performed. Developmental toxicity including teratogenicity was observed in animal studies at doses that correspond approximately to the maximum recommended human dose (see TOXICOLOGY). Hydroxocobalamin levels were detected in urine for some patients up to 35 days following treatment with Cyanokit ${ }^{\oplus}$ indicating that elimination of Cyanokit ${ }^{\circledR}$ from the body may not be completed after 35 days. Based on these data, it is recommended to practice adequate methods of contraception for 2 months following Cyanokit ${ }^{\circledast}$ treatment.

Skin: Photosensitivity - Hydroxocobalamin absorbs visible light in the UV spectrum. It therefore has potential to cause photosensitivity. While it is not known if the skin redness predisposes to photosensitivity, patients should be advised to avoid direct sun while their skin remains discoloured.

\section{$\underline{\text { Special Populations }}$}

Pregnant Women: Animal studies have shown teratogenic effects following daily exposure throughout organogenesis (see TOXICOLOGY). There are no adequate and well-controlled studies in pregnant women. However, treatment of maternal/fetal cyanide poisoning may be life-saving. The effect of Cyanokit on labour and delivery is unknown.

Nursing Women: It is not known whether hydroxocobalamin is excreted in human milk. Because of the unknown potential for adverse reactions in nursing infants, discontinue nursing after Cyanokit ${ }^{\circledast}$ treatment.

Renal Impairment: The safety and effectiveness of Cyanokit have not been studied in patients with renal impairment. Hydroxocobalamin and cyanocobalamin are eliminated unchanged by the kidneys. Oxalate crystals have been observed in the urine of both healthy subjects given hydroxocobalamin and patients treated with hydroxocobalamin following suspected cyanide poisoning.

Hepatic Impairment: The safety and effectiveness of Cyanokit ${ }^{\circledR}$ have not been studied in patients with hepatic impairment.

\section{Monitoring and Laboratory Tests}

Effects on blood cyanide assay: Hydroxocobalamin will lower blood cyanide concentrations. While determination of blood cyanide concentration is not required and must not delay treatment with hydroxocobalamin, it may be useful for documenting cyanide poisoning. If a cyanide blood level determination is planned, it is recommended to draw the blood sample before initiation of treatment with Cyanokit.

Interference with burn assessment: Because of its deep red colour, hydroxocobalamin has the potential to induce a red colouration of the skin and therefore may interfere with burn assessment. However, skin lesions, edema, and pain are highly suggestive of burns.

Interference with laboratory tests: Because of its deep red colour, hydroxocobalamin has the potential to interfere with determination of laboratory parameters (e.g., clinical chemistry, hematology, coagulation, and urine parameters) (Table 2). In vitro tests indicate that the extent and duration of the interference is dependent on numerous factors such as the dose of hydroxocobalamin, analyte, analyte concentration, 
methodology, analyzer, concentrations of cobalamins-(III) including cyanocobalamin and partially the time between sampling and measurement. Based on in vitro studies and pharmacokinetic data obtained in healthy volunteers the following table describes interference with laboratory tests that may be observed following a $5 \mathrm{~g}$ dose of hydroxocobalamin. Interference following a $10 \mathrm{~g}$ dose can be expected to last up to an additional 24 hours. The extent and duration of interference in cyanidepoisoned patients may differ according to the severity of intoxication. Results may vary considerably from one analyzer to another, therefore, caution is required when reporting and interpreting laboratory results.

Table 2. Laboratory Interference Observed with in vitro Samples of Hydroxocobalamin

\begin{tabular}{|c|c|c|c|c|c|}
\hline $\begin{array}{l}\text { Laboratory } \\
\text { Parameter }\end{array}$ & $\begin{array}{l}\text { No Interfer- } \\
\text { ence } \\
\text { Observed }\end{array}$ & $\begin{array}{l}\text { Artificially } \\
\text { Increased }^{\text {a }}\end{array}$ & $\begin{array}{l}\text { Artificially } \\
\text { Decreased }^{\mathrm{a}}\end{array}$ & $\begin{array}{l}\text { Unpre- } \\
\text { dictable }^{c}\end{array}$ & $\begin{array}{l}\text { Duration of } \\
\text { Interfer- } \\
\text { ence }\end{array}$ \\
\hline $\begin{array}{l}\text { Clinical } \\
\text { Chemistry }\end{array}$ & $\begin{array}{l}\text { Calcium } \\
\text { Sodium } \\
\text { Potassium } \\
\text { Chloride } \\
\text { Urea } \\
\text { Gamma } \\
\text { glutamyl } \\
\text { transferase } \\
\text { (GGT) }\end{array}$ & $\begin{array}{l}\text { Creatinine } \\
\text { Total and } \\
\text { conjugate } \\
\text { bilirubin }^{b} \\
\text { Triglycerides } \\
\text { Cholesterol } \\
\text { Total protein } \\
\text { Glucose } \\
\text { Albumin } \\
\text { Alkaline } \\
\text { phospha- } \\
\text { tase }\end{array}$ & $\begin{array}{l}\text { Alanine } \\
\text { aminotrans- } \\
\text { ferase } \\
\text { (ALT) } \\
\text { Amylase }\end{array}$ & $\begin{array}{l}\text { Phosphate } \\
\text { Uric Acid } \\
\text { Aspartate } \\
\text { aminotrans- } \\
\text { ferase (AST) } \\
\text { Creatine } \\
\text { Kinase } \\
\text { (CK) } \\
\text { Creatine } \\
\text { Kinase } \\
\text { isoenzyme } \\
\text { MB (CKMB) } \\
\text { Lactate } \\
\text { dehydro- } \\
\text { genase } \\
\text { (LDH) }\end{array}$ & $\begin{array}{l}24 \text { hours } \\
\text { with the } \\
\text { exception of } \\
\text { bilirubin (up } \\
\text { to } 4 \text { days) }\end{array}$ \\
\hline Hematology & $\begin{array}{l}\text { Erythrocytes } \\
\text { Hematocrit } \\
\text { Mean } \\
\text { corpuscular } \\
\text { volume } \\
\text { (MCV) } \\
\text { Leukocytes } \\
\text { Lympho- } \\
\text { cytes } \\
\text { Monocytes } \\
\text { Eosinophils } \\
\text { Neutrophils } \\
\text { Platelets }\end{array}$ & $\begin{array}{l}\text { Hemoglobin } \\
(\mathrm{Hb}) \\
\text { Mean cor- } \\
\text { puscular } \\
\text { hemoglobin } \\
(\mathrm{MCH}) \\
\text { Mean cor- } \\
\text { puscular } \\
\text { hemoglobin } \\
\text { concentra- } \\
\text { tion (MCHC) } \\
\text { Basophils }\end{array}$ & & & $\begin{array}{l}12-6 \\
\text { hours }\end{array}$ \\
\hline Coagulation & & & & $\begin{array}{l}\text { Activated } \\
\text { partial } \\
\text { thromo- } \\
\text { plastin time } \\
\text { (aPTT) } \\
\text { Prothrombin } \\
\text { time (PT) } \\
\text { Quick or INR }\end{array}$ & $\begin{array}{l}24-48 \\
\text { hours }\end{array}$ \\
\hline Urinalysis & & $\begin{array}{l}\text { pH (with } \\
\text { doses } \geq 5 \mathrm{~g} \text { ) } \\
\text { Glucose } \\
\text { Protein } \\
\text { Erythrocytes } \\
\text { Leukocytes } \\
\text { Ketones } \\
\text { Bilirubin } \\
\text { Urobilinogen } \\
\text { Nitrite }\end{array}$ & $\begin{array}{l}\mathrm{pH} \text { (with } \\
\text { equivalent } \\
\text { doses of } \\
<5 \mathrm{~g} \text { ) }\end{array}$ & & $\begin{array}{l}8 \text { hours } \\
\text { up to } 8 \\
\text { days; colour } \\
\text { changes } \\
\text { may persist } \\
\text { up to } 28 \\
\text { days }\end{array}$ \\
\hline
\end{tabular}

$a \geq 10 \%$ interference observed on at least 1 analyzer

${ }^{b}$ Artificially decreased using the diazo method

${ }^{\mathrm{C}}$ Inconsistent results

Analyzers used: ACL Futura (Instrumentation Laboratory), AxSYM"/Architect'm (Abbott), BM Coasys ${ }^{110}$ (Boehringer Mannheim), CellDyn 3700 (Abbott), Clinitek 500 (Bayer), Cobas Integra ${ }^{\oplus} 700,400$ (Roche), Gen-S Coultronics, Hitachi 917, STA ${ }^{\circledast}$ Compact, Vitros ${ }^{\circledast} 950$ (Ortho Diagnostics).

Interference with hemodialysis machines: Because of its deep red colour, hydroxocobalamin may cause hemodialysis machines to shut down due to an erroneous detection of a 'blood leak'. This should be considered before hemodialysis is initiated in patients treated with hydroxocobalamin.
ADVERSE REACTIONS (see Supplemental Product Information for full listing): Adverse Drug Reaction Overview: Serious adverse reactions with hydroxocobalamin include allergic reactions and increases in blood pressure (see WARNINGS AND PRECAUTIONS). A total of 347 subjects were exposed to hydroxocobalamin in clinical studies. Of these 347 subjects, 245 patients had suspected exposure to cyanide at the time of hydroxocobalamin administration. The remaining 102 subjects were healthy volunteers who had not been exposed to cyanide at the time of hydroxocobalamin administration. Most patients will experience a reversible red colouration of the skin and mucous membranes that may last up to 15 days after administration of Cyanokit. All patients will show a dark red colouration of the urine that is quite marked during the three days following administration. Urine colouration may last up to 35 days after administration of Cyanokit.

Post-Market Adverse Drug Reactions: The following adverse events have been reported in post-marketing surveillance. The relationship of these events to Cyanokit ${ }^{\circledR}$ use is not known. Smoke inhalation and cyanide exposure may have contributed to these events: abnormal laboratory tests, pulmonary edema, cardiac arrest, rena failure - in some cases requiring dialysis, and transient impairment of renal function. To monitor drug safety, Health Canada collects information on serious and unexpected effects of drugs. If you suspect you have had a serious or unexpected reaction to this drug, you may notify Health Canada by toll-free telephone: 1-866-234-2345.

DRUG INTERACTIONS (also see Supplemental Product Information): Overview: Due to its high molecular weight, hydroxocobalamin is unlikely to interact with or inhibit CYP450 enzymes at clinically relevant concentrations. It is therefore considered to have low potential to be involved in drug-drug interactions with drugs that are substrates of CYP450. Physical incompatibility (particle formation) and chemical incompatibility were observed with the mixture of hydroxocobalamin in solution with selected drugs that are frequently used in resuscitation efforts. Hydroxocobalamin is also chemically incompatible with sodium thiosulfate and sodium nitrite and has been reported to be incompatible with ascorbic acid. Therefore, these and other drugs should not be administered simultaneously through the same IV line as hydroxocobalamin (see DOSAGE AND ADMINISTRATION).

Drug-Drug Interactions: No formal drug-drug interaction studies with hydroxocobalamin have been done.

Drug-Food Interactions: No formal drug-food interaction studies with hydroxocobalamin have been done.

\section{$\Delta \theta$ Administration}

DOSAGE AND ADMINISTRATION: Dosing Considerations: Comprehensive treatment of acute cyanide intoxication requires support of vital functions. Cyanokit ${ }^{\circledast}$ should be administered in conjunction with appropriate airway, ventilatory and circulatory support. The safety of administering other cyanide antidotes simultaneously with Cyanokit ${ }^{\circledR}$ has not been established. If the decision is made to administer another cyanide antidote with Cyanokit, ${ }^{\circledR}$ these medicinal products must not be administered simultaneously through the same intravenous line.

Recommended Dose and Dosage Adjustment: In adults, the initial dose of Cyanokit ${ }^{\circledast}$ is $5 \mathrm{~g}$ administered as an IV infusion. Depending on the severity of the poisoning and the clinical response, a second dose may be administered by IV infusion. The maximum recommended total dose is $10 \mathrm{~g}$. In infants and adolescents, the initia dose of Cyanokit ${ }^{\circledR}$ is $70 \mathrm{mg} / \mathrm{kg}$ body weight not exceeding $5 \mathrm{~g}$. Depending on the severity of the poisoning and the clinical response, a second dose may be administered by IV infusion. The maximum recommended total dose is $140 \mathrm{mg} / \mathrm{kg}$ body weight not exceeding $10 \mathrm{~g}$ (Table 3).

Table 3. Initial Dosing Guidelines in Infants and Adolescents

\begin{tabular}{|l|c|c|c|c|c|c|c|}
\hline Body weight in $\mathrm{kg}$ & $\mathbf{5}$ & $\mathbf{1 0}$ & $\mathbf{2 0}$ & $\mathbf{3 0}$ & $\mathbf{4 0}$ & $\mathbf{5 0}$ & $\mathbf{6 0}$ \\
\hline Initial dose in $\mathrm{g}$ & 0.35 & 0.70 & 1.40 & 2.10 & 2.80 & 3.50 & 4.20 \\
\hline Initial dose in $\mathrm{mL}$ & 14 & 28 & 56 & 84 & 112 & 140 & 168 \\
\hline
\end{tabular}

Use in Renal and Hepatic Impairment: Although the safety and efficacy of hydroxocobalamin has not been studied in patients with renal or hepatic impairment, Cyanokit ${ }^{\circledR}$ is administered as emergency therapy in an acute, life-threatening situation only, and no dosage adjustment is required in these patients.

Administration: The initial dose of hydroxocobalamin for adults is $5 \mathrm{~g}$ (i.e., two $2.5 \mathrm{~g}$ vials or one $5 \mathrm{~g}$ vial) administered as an intravenous (IV) infusion over 15 minutes (approximately $15 \mathrm{~mL} / \mathrm{min}$ ). Depending upon the severity of the poisoning and the 
clinical response, a second dose of $5 \mathrm{~g}$ may be administered by IV infusion for a total dose of $10 \mathrm{~g}$. The rate of infusion for the second dose ranges from 15 minutes (for patients who are extremely unstable) to 2 hours depending on the patient's condition.

Table 4. Reconstitution

\begin{tabular}{|l|c|c|c|}
\hline Dose per Vial & $\begin{array}{c}\text { Volume of Diluent } \\
\text { to be } \\
\text { Added to Vial }\end{array}$ & $\begin{array}{c}\text { Approximate } \\
\text { Available Volume }\end{array}$ & $\begin{array}{c}\text { Nominal } \\
\text { Concentration } \\
\text { per } \mathrm{mL}\end{array}$ \\
\hline $2.5 \mathrm{~g}$ & $100 \mathrm{~mL}$ & Approx. $100 \mathrm{~mL}$ & $25 \mathrm{mg} / \mathrm{mL}$ \\
\hline $5 \mathrm{~g}$ & $200 \mathrm{~mL}$ & Approx. $200 \mathrm{~mL}$ & $25 \mathrm{mg} / \mathrm{mL}$ \\
\hline
\end{tabular}

$2.5 \mathrm{~g}$ Vial: Each $2.5 \mathrm{~g}$ vial is to be reconstituted with $100 \mathrm{~mL}$ of diluent using the supplied sterile transfer device. Sodium chloride $9 \mathrm{mg} / \mathrm{mL}(0.9 \%)$ solution for injection is the recommended diluent. Only when sodium chloride $9 \mathrm{mg} / \mathrm{mL}(0.9 \%)$ solution for injection is not available, Lactated Ringer solution or $5 \%$ glucose can also be used. The Cyanokit ${ }^{\circledR} 2.5 \mathrm{~g}$ vial is to be rocked or inverted for at least 30 seconds to mix the solution. It must not be shaken as shaking the vial may cause foam and therefore may make checking reconstitution less easy.

$5 \mathrm{~g}$ Vial: Each $5 \mathrm{~g}$ vial is to be reconstituted with $200 \mathrm{~mL}$ of diluent using the supplied sterile transfer device. Sodium chloride $9 \mathrm{mg} / \mathrm{mL}(0.9 \%)$ solution for injection is the recommended diluent. Only when sodium chloride $9 \mathrm{mg} / \mathrm{mL}(0.9 \%)$ solution for injection is not available, Lactated Ringer solution or $5 \%$ glucose can also be used. The Cyanokit ${ }^{\circledR} \mathrm{g}$ vial is to be rocked or inverted for at least 60 seconds to mix the solution. It must not be shaken as shaking the vial may cause foam and therefore may make checking reconstitution less easy. Because the reconstituted solution is a dark red solution, some insoluble particles may not be seen. The intravenous infusion set provided in the kit must therefore be used as it includes an appropriate filter and is to be primed with the reconstituted solution. Repeat this procedure if necessary with the second vial.

Incompatibility Information: Physical incompatibility (particle formation) and chemical incompatibility were observed with the mixture of hydroxocobalamin in solution with selected drugs that are frequently used in resuscitation efforts. Hydroxocobalamin is also chemically incompatible with sodium thiosulfate and sodium nitrite and has been reported to be incompatible with ascorbic acid. Therefore, these and other drugs must not be administered simultaneously through the same IV line as hydroxocobalamin. Simultaneous administration of hydroxocobalamin and blood products (whole blood, packed red cells, platelet concentrate and/or fresh frozen plasma) through the same IV line is not recommended. However, blood products and hydroxocobalamin can be administered simultaneously using separate IV lines (preferably on contralateral extremities, if peripheral lines are being used).

Storage of Reconstituted Drug Product: Once reconstituted, hydroxocobalamin is stable for up to 6 hours at a temperature between $2^{\circ} \mathrm{C}$ and $40^{\circ} \mathrm{C}\left(35.6^{\circ} \mathrm{F}\right.$ and $\left.104^{\circ} \mathrm{F}\right)$. Do not freeze. Any reconstituted product not used by 6 hours should be discarded.

\section{Supplemental Product Information}

ADVERSE REACTIONS: Systematic collection of adverse events was not done in all clinical studies involving known or suspected cyanide-poisoning victims who were treated with hydroxocobalamin. The interpretation of causality in these studies is limited due to lack of a control group and due to circumstances of administration (e.g., use in fire victims).

Clinical Trial Adverse Drug Reactions: Because clinical trials are conducted under very specific conditions the adverse reaction rates observed in the clinical trials may not reflect the rates observed in practice and should not be compared to the rates in the clinical trials of another drug. Adverse drug reaction information from clinical trials is useful for identifying drug-related adverse events and for approximating rates.

Experience in Healthy Subjects: A double-blind, randomized, placebo-controlled, single-ascending dose $(2.5,5,7.5$, and $10 \mathrm{~g})$ study was conducted to assess the safety, tolerability, and pharmacokinetics of hydroxocobalamin in 136 healthy adult subjects. Because of the dark red colour of hydroxocobalamin, the two most frequently occurring adverse reactions were chromaturia (red-coloured urine) which was reported in all subjects receiving a $5 \mathrm{~g}$ dose or greater; and erythema (skin redness), which occurred in most subjects receiving a $5 \mathrm{~g}$ dose or greater. Adverse reactions reported in at least $1 \%$ of the $5 \mathrm{~g}$ dose group and corresponding rates in the $10 \mathrm{~g}$ and placebo groups are shown in Table 5 .
Table 5. Incidence of Adverse Reactions Occurring in $\geq 1 \%$ of Healthy Subjects in $5 \mathrm{~g}$ Dose Group and Corresponding Incidence in $10 \mathrm{~g}$ Dose Group and Placebo

\begin{tabular}{|c|c|c|c|c|}
\hline & \multicolumn{2}{|c|}{$5 \mathrm{~g}$ Dose Group } & \multicolumn{2}{|c|}{$10 \mathrm{~g}$ Dose Group } \\
\hline & $\begin{array}{l}\text { Hydroxo- } \\
\text { cobalamin }\end{array}$ & Placebo & $\begin{array}{l}\text { Hydroxo- } \\
\text { cobalamin }\end{array}$ & Placebo \\
\hline & $N=66$ & $\mathrm{~N}=22$ & $\mathrm{~N}=18$ & $N=6$ \\
\hline Adverse Drug Reaction & $\mathrm{n}(\%)$ & $\mathrm{n}(\%)$ & $\mathrm{n}(\%)$ & $\mathrm{n}(\%)$ \\
\hline \multicolumn{5}{|l|}{ Eye disorder } \\
\hline Eye redness & $2(3)$ & 0 & $1(6)$ & 0 \\
\hline \multicolumn{5}{|l|}{ Renal and Urinary Disorders } \\
\hline $\begin{array}{l}\text { Chromaturia } \\
\text { (red coloured urine) }\end{array}$ & $66(100)$ & 0 & $18(100)$ & 0 \\
\hline Pollakiuria (frequent urination) & $1(2)$ & 0 & 0 & 0 \\
\hline \multicolumn{5}{|c|}{ Skin and subcutaneous tissue Disorders } \\
\hline Erythema & $62(94)$ & 0 & $18(100)$ & 0 \\
\hline Rash* $^{*}$ & $14(21)$ & 0 & $3(17)$ & 0 \\
\hline
\end{tabular}

Immune Disorders

\begin{tabular}{|l|c|c|c|c|}
\hline Face edema & $1(2)$ & 0 & 0 & 0 \\
\hline Pruritus & $1(2)$ & 0 & $3(17)$ & 0 \\
\hline Urticaria & $1(2)$ & 0 & 0 & 0 \\
\hline
\end{tabular}

Investigations

\begin{tabular}{l|c|c|c|c|}
\hline Blood amylase increased & $1(2)$ & 0 & 0 & 0 \\
\hline Blood pressure increased & $12(18)$ & 0 & $5(28)$ & 0 \\
\hline $\begin{array}{l}\text { Lymphocyte percent } \\
\text { decreased }\end{array}$ & $5(8)$ & 0 & $3(17)$ & 0 \\
\hline
\end{tabular}

Gastrointestinal disorders

\begin{tabular}{|l|c|c|c|c|}
\hline Abdominal discomfort & $2(3)$ & 0 & $2(11)$ & 0 \\
\hline Flatulence & $1(2)$ & 0 & 0 & 0 \\
\hline Loose stools & $1(2)$ & 0 & 0 & 0 \\
\hline Nausea & $4(6)$ & $1(5)$ & $2(11)$ & 0 \\
\hline Vomiting & $2(3)$ & 0 & 0 & 0 \\
\hline
\end{tabular}

Nervous System Disorders

\begin{tabular}{|l|c|c|c|c|}
\hline Dizziness & $2(3)$ & 0 & $1(6)$ & 0 \\
\hline Headache & $4(6)$ & $1(5)$ & $6(33)$ & 0 \\
\hline
\end{tabular}

General disorders and administrative site conditions

\begin{tabular}{|l|c|c|c|c|}
\hline Chest discomfort & $3(5)$ & 0 & $2(11)$ & 0 \\
\hline Discomfort & $1(2)$ & 0 & 0 & 0 \\
\hline Feeling hot and/or cold & $2(3)$ & 0 & 0 & 0 \\
\hline Infusion site reaction & $4(6)$ & 0 & $7(39)$ & 0 \\
\hline
\end{tabular}

Musculoskeletal and connective tissue disorders

\begin{tabular}{|l|c|c|c|c|}
\hline Joint/back pain & $2(3)$ & 0 & 0 & 0 \\
\hline Psychiatric disorders \\
\hline Restlessness & $2(3)$ & 0 & 0 & 0 \\
\hline Respiratory, thoracic and mediastinal disorders \\
\hline Dyspnea & $1(2)$ & 0 & 0 & 0 \\
\hline Sore or dry throat & $3(5)$ & 0 & $3(17)$ & 0 \\
\hline
\end{tabular}

* Rashes were predominately acneiform 


\section{Less Common Adverse Drug Reactions Occurring at a rate of less than 1\%}

Eye disorders: Swelling, irritation.

Gastrointestinal disorders: Dyspepsia, diarrhea, dysphagia, hematochezia.

General disorders and administration site conditions: Peripheral edema.

Immune system disorders: Allergic reactions including angioneurotic edema and skin eruption (see WARNINGS AND PRECAUTIONS)

Nervous system disorders: Memory impairment.

Respiratory, thoracic and mediastinal disorders: Pleural effusion.

Vascular disorders: Hot flush.

Experience in Known and Suspected Poison Victims: Four open-label, uncontrolled, clinical studies (one of which was prospective and three of which were retrospective) were conducted in known or suspected cyanide-poisoning victims. A total of 245 patients received hydroxocobalamin treatment in these studies. Systematic collection of adverse events was not done in all of these studies and interpretation of causality is limited due to the lack of a control group and due to circumstances of administration (e.g., use in fire victims). Adverse reactions reported in these studies listed by system organ class included:

Cardiac disorders: Ventricular extrasystoles, an increase in heart rates, electrocardiogram repolarization abnormality.

Adverse reactions common to both the studies in known or suspected cyanide poisoning victims and the study in healthy volunteers are listed in the healthy volunteer section of the Product Monograph only and are not duplicated in this list.

Abnormal Hematologic and Clinical Chemistry Findings: Cyanokit ${ }^{\circledR}$ may cause red discolouration of the plasma, which may cause artificial elevation or reduction in the levels of certain laboratory parameters (see WARNINGS AND PRECAUTIONS). White blood cell counts (WBC) showed a slight and transient increase in mean values from baseline at 2 to 12 hours after treatment in healthy subjects, and small decreases in serum sodium levels were also observed. Changed values generally remained within normal ranges. Other minor and transient changes in hematology and clinica chemistry findings were considered due to interference by hydroxocobalamin or due to individual variation.

DRUG INTERACTIONS: Drug-Herb Interactions: Interactions with herbal products have not been established.

Drug-Laboratory Interactions: Because of its deep red colour, hydroxocobalamin has been found to interfere with colourimetric determination of certain laboratory parameters (e.g., clinical chemistry, hematology, coagulation, and urine parameters). In vitro tests indicated that the extent and duration of the interference are dependent on numerous factors such as the dose of hydroxocobalamin, analyte, methodology, analyzer, hydroxocobalamin concentration, and partially on the time between sampling and measurement. Based on in vitro studies and pharmacokinetic data obtained in healthy volunteers, Table 2 describes laboratory interference that may be observed following a $5 \mathrm{~g}$ dose of hydroxocobalamin (see WARNINGS AND PRECAUTIONS) Interference following a $10 \mathrm{~g}$ dose can be expected to last up to an additional 24 hours. The extent and duration of interference in cyanide-poisoned patients may differ Results may vary substantially from one analyzer to another; therefore, caution should be used when reporting and interpreting laboratory results.

\section{OVERDOSAGE:}

For management of a suspected drug overdose, contact your Regional Poison Control Centre.

Limited data are available about overdose with Cyanokit. Doses as high as $15 \mathrm{~g}$ have been administered without reported specific dose related adverse reactions. If overdose occurs, treatment is directed to the management of symptoms. Hemodialysis may be effective in such a circumstance, but is only indicated in the event of significant hydroxocobalamin-related toxicity. Because of its deep red colour, hydroxocobalamin may interfere with the performance of hemodialysis machines (see WARNINGS AND PRECAUTIONS, Monitoring and Laboratory Tests).

Product Monograph available on request.

References: 1. CYANOKIT ${ }^{\circledR}$ (Hydroxocobalamin) Product Monograph, EMD Serono October, 2011. 


\section{CYANOKIT'5g}

\section{If you encounter a smoke inhalation victim, they may have cyanide poisoning}

\section{If you suspect cyanide poisoning, respond with Cyanokit ${ }^{\circ}$}

Cyanokit ${ }^{\circ}$ contains hydroxocobalamin, an antidote indicated for the treatment of known or suspected cyanide poisoning. Cyanokit is to be administered together with appropriate decontamination and supportive measures!

- Designed for use at the scene or in the hospital

- Now in one $5 \mathrm{~g}$ vial

To order Cyanokit ${ }^{\circ}$ or for more information,

call EMD Serono Customer Care at 1-800-387-9749

Warnings and Precautions: In addition to Cyanokit, treatment of cyanide poisoning must include immediate attention to airway patency, adequacy of oxygenation and hydration, cardiovascular support, and management of any seizure activity. Consideration should be given to decontamination measures based on the route of exposure. Cyanokit does not substitute for oxygen therapy and must not delay the set up of the above measures.

Contraindications: None.

Adverse events: Systematic collection of adverse events was not done in all clinical studies involving known or suspected cyanide-poisoning victims who were treated with hydroxocobalamin. The interpretation of causality in these studies is limited due to lack of a control group and due to circumstances of administration (e.g., use in fire victims). The most common adverse events $(>5 \%)$ in healthy subjects who received hydroxocobalamin are reversible red colouration of the skin and mucous membranes (erythema), marked dark red colouration of the urine (chromaturia), eye redness, rash (acneiform), pruritus, transient increase in blood pressure, decrease in the percentage of lymphocytes, abdominal discomfort, nausea, dizziness, headache, chest discomfort, injection site reaction, and sore or dry throat. Other less common adverse events $(<5 \%)$ include: pollakiuria (frequent urination), face edema, urticaria, increase in blood amylase levels, flatulence, loose stools, vomiting, general discomfort, feeling hot and/or cold, joint/back pain, restlessness, dyspnea, eye swelling, eye irritation, dyspepsia, diarrhea, dysphagia, hematochezia, peripheral edema, memory impairment, pleural effusion, and allergic reactions including angioneurotic edema and skin eruption.

Please consult the Cyanokit Product Monograph for further information.

Cyanokit is a registered trademark of Merck Santé S.A.S.

Importer \& Distributor of Cyanokit৫: EMD Serono, A Division of EMD Inc., Canada • 2695 North Sheridan Wav, Suite 200, Mississauga, Ontario L5K 2N6 Canada www.emdserono.ca • An affiliate of Merck KGaA, Darmstadt, Germany

$\overparen{P A A B}^{*}$ Member

EMDSerono

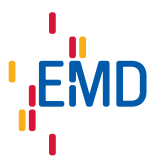




\section{Medical Administration and Leadership}
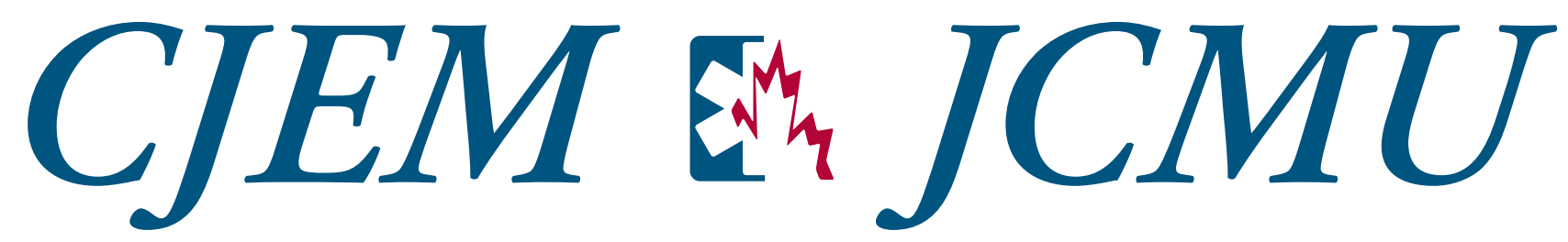

MARCH/MARS 2013 Vol. 15 No. 2

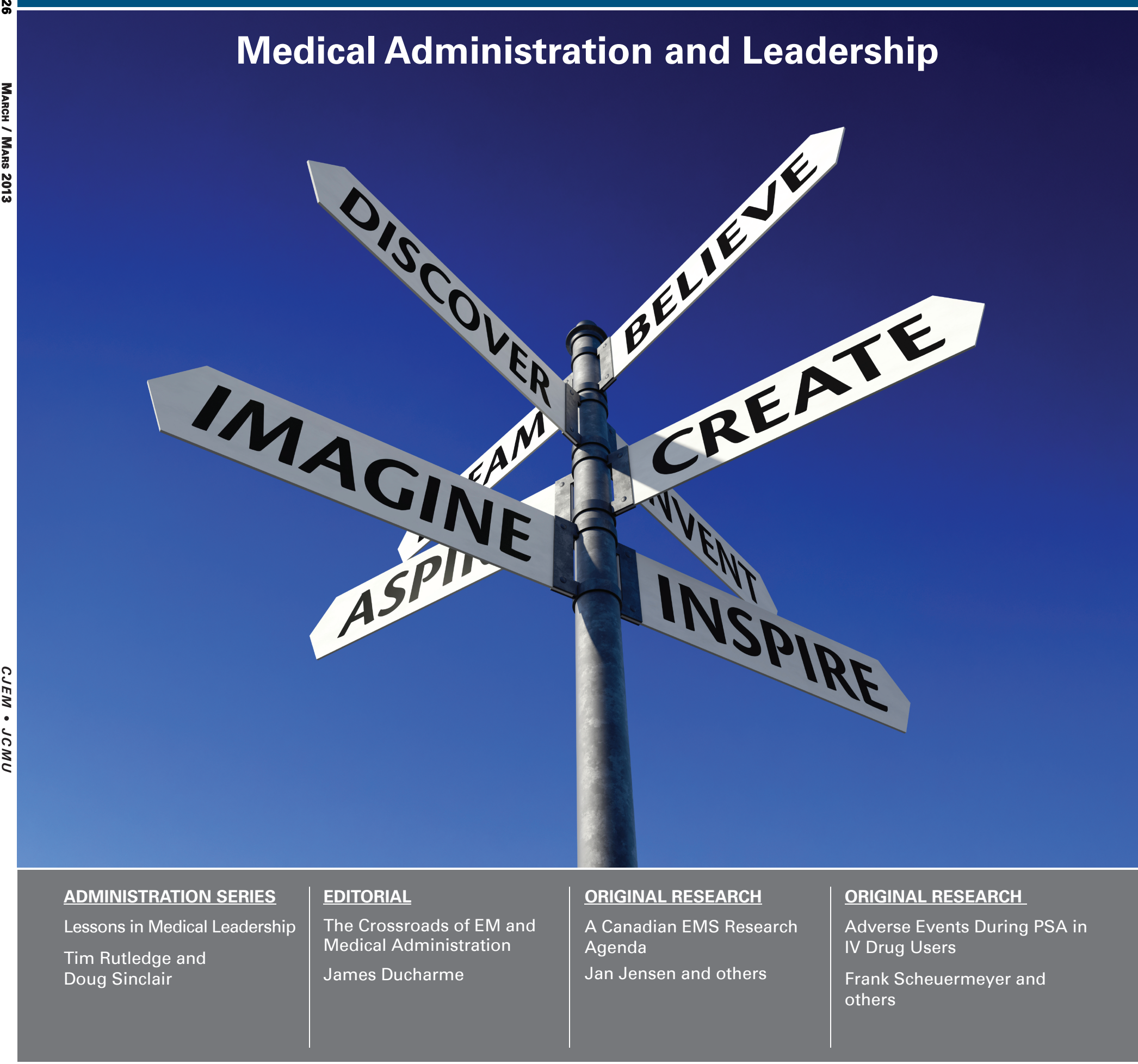

FM/ 


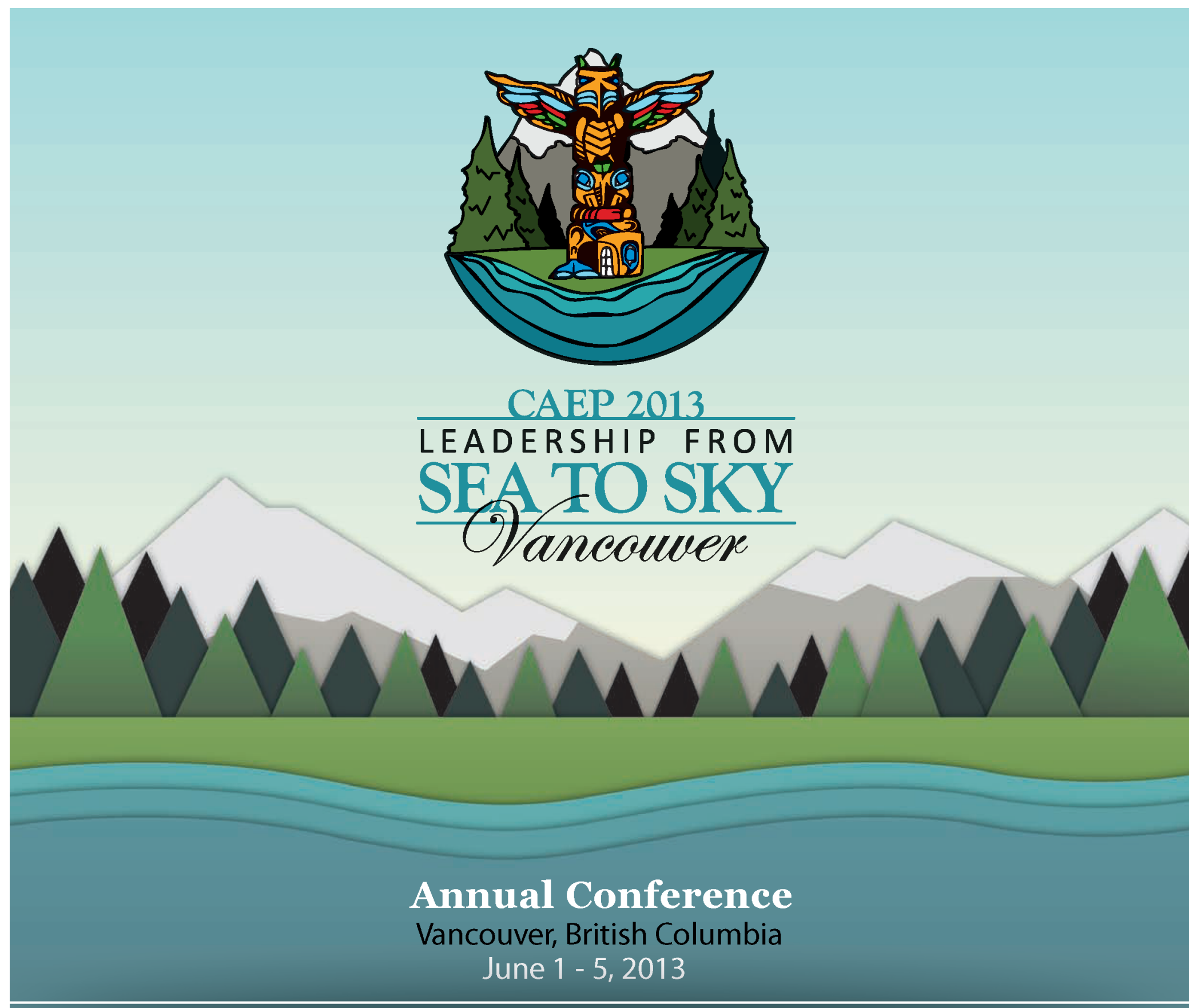

\section{REGISTRATION NOW OPEN!}

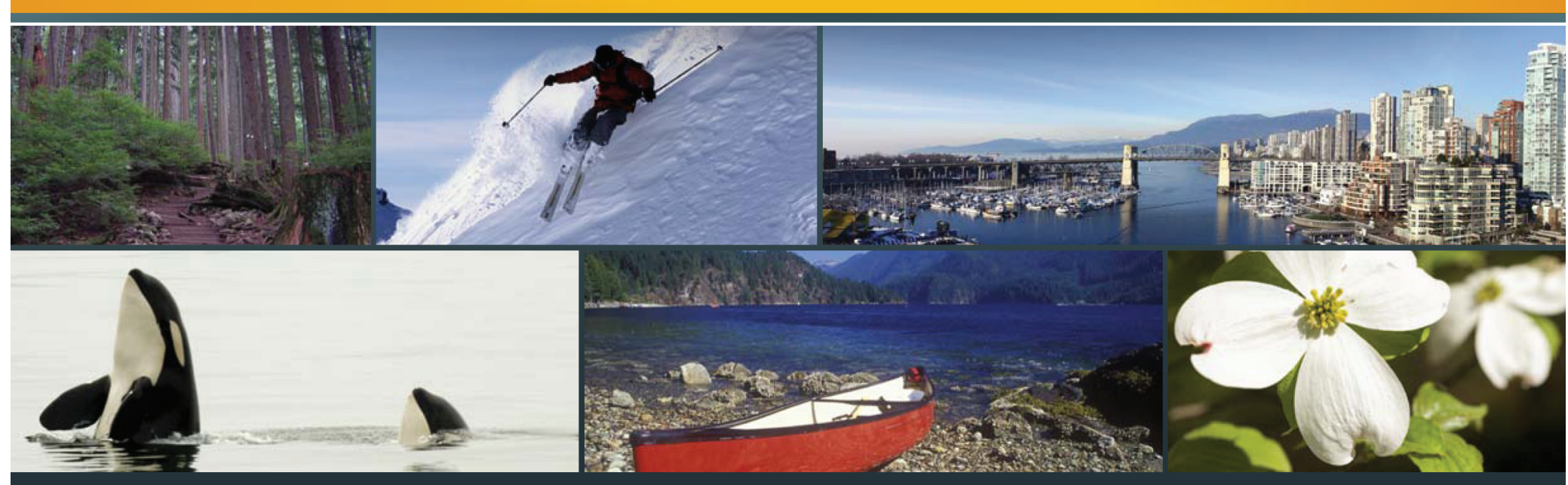

Eith 


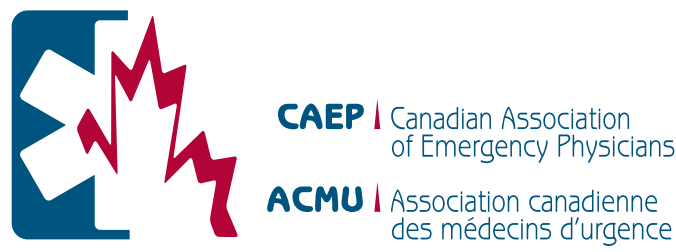

On behalf of the CAEP Research Committee, I offer sincere thanks to our Grant and Abstract Reviewers for your time and expertise during the 2013 competition. We have introduced a new submission system this year, which has been a steep learning curve for everyone involved. The patience and flexibility of our reviewers is greatly appreciated. I also thank Ms. Jennifer Lafreniere at CAEP for her help and support through the review process this year.

Thank you CAEP Reviewers!

Please visit the revised CAEP Research Section at www.caep.ca/research where you will find further information on CAEP research, links to resources, and our new Research Networks section.

Regards,

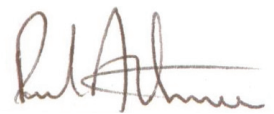

Dr. Paul Atkinson

Chair, CAEP Research committee

Reviewers for the 2012-2013 Grant and Abstract Competition were:

Dr. Riyad Abu-Laban
Dr. Stacy Ackroyd
Dr. Marc Afilalo
Dr. Dug Andrusiek
Dr. Patrick Archambault
Dr. Paul Atkinson
Dr. Benoit Bailey
Dr. Bjug Borgundvaag
Dr. Robert Brison
Dr. Michael Bullard
Dr. Sam Campbell
Dr. Alix Carter
Dr. Jean-Marc Chauny
Dr. Bruce Cload
Dr. Jim Connolly
Dr. Valerie De Maio
Dr. Barry Diner
Dr. Sandy Dong
Dr. Robert Dunne
Dr. Marcia Edmonds
Dr. Marcel Emond
Dr. Ken Farion
Dr. Richard Fleet
Dr. Jason Frank
Dr. James French
Dr. Ran Goldman

Dr. Sophie Gosselin Dr. Eric Grafstein Prof. Colin Graham

Dr. Jocelyn Gravel Dr. Rob Green

Dr. Amanda Hanson Dr. Tim Harris

Dr. Anwar Hasan

Dr. Andrew Healey

Dr. Corinne Hohl

Dr. Robert Jarman

Dr. Carl Jarvis

Dr. Hein Lamprecht Dr. Eddy Lang

Dr. David Lewis

Dr. Tim Lynch

Dr. Andrew MacPherson

Dr. Dan Mayer

Dr. Shelley McLeod

Dr. Andrew McRae

Dr. Mark Mensour

Dr. Lester Mercuur

Dr. Angelo Mikrogianakis

Dr. Wanda Millard

Dr. Ken Milne

Dr. James Olson
Dr. Howard Ovens

Dr. Merril Pauls

Dr. Jeff Perry

Dr. Martin Pusic

Dr. Tia Renouf

Dr. Brian Rowe

Dr. Frank Scheuermeyer

Dr. Nicola Schiebel

Dr. Michael Schull

Dr. Eli Segal

Dr. Jonathon Sherbino

Dr. Michael Shuster

Dr. Douglas Sinclair

Dr. Marco Sivilotti

Dr. Carolyn Snider

Dr. Melanie Stander

Dr. Rob Stenstrom

Dr. Ian Stiell

Dr. Jo-Ann Talbot

Dr. Karl Theakston

Dr. Christian Vaillancourt

Dr. Laurent Vanier

Dr. Renee Vilneff

Prof. Lee Wallis

Prof. Joseph Wood

Dr. Andrew Worster 